REPORTS OF MORPHOLOGY
Official Journal of the Scientific Society of Anatomists,
Histologists, Embryologists and Topographic Anatomists
of Ukraine
journal homepage: https://morphology-journal.com

\title{
Morphological features of the wall of common bile duct under the conditions of experimental opioid exposure
}

\author{
Mateshuk-Vatseba L.R., Hirniak I.I., Pidvalna U.Y.
}

Danylo Halytsky Lviv National Medical University, Lviv, Ukraine

\section{ARTICLE INFO}

Received: 15 June, 2020

Accepted: 20 July, 2020

UDC: $611.367-018.1: 615.212 .7]-08$

\section{CORRESPONDING AUTHOR}

e-mail: Ivatseba@gmail.com Mateshuk-Vatseba L.R.

\begin{abstract}
The morphological condition of the bile ducts remains one of the most important problems of modern medical science. In order to obtain an analgesic effect in patients with acute cholangitis, opioids are often used. However, information on the effectiveness of opioids in the treatment of pathological conditions of the bile ducts is contradictory. The rapidly progressive destruction of the intrahepatic bile ducts associated with the use of narcotic agents has been described. Further study of the effect of opioids on the structural organization of the common bile duct is relevant. In order to establish the morphological state of the common bile duct under conditions of long-term opioid exposure, a study was performed on 24 sexually mature white male rats, aged 3.5-5.0 months and weighing 180-200 g, which were injected intramuscularly with Nalbuphine for 6 weeks. The study material is represented by histological specimens of the common bile duct of white rats. The "Aver Media" computer system was used to photograph microspecimens. The "ImageJ" computer program was used to measure the diameter of the lumen and the wall thickness of the common bile duct. After 2 weeks of Nalbuphine administration to white rats, plethora of wall microvessels and a significant increase in the longitudinal diameter of the lumen of the common bile duct were observed. After 4 weeks of the experiment, the common bile duct was dilated, the transverse and longitudinal diameters of its lumen almost doubled, pathological changes in its wall had all the signs of inflammation. In the later stages of the experiment (introduction of Nalbuphine for 6 weeks), the pathological changes increased and manifested by destructuring the wall of the common bile duct, disorganization of cholangiocytes, thinning of the cell layer due to detachment of cholangiocytes, polymorphism of their nuclei, destruction of intercellular junctions, stratification of its own plate, vacuolar dystrophy of the muscular membrane "varicose" expansion of venules, significant smooth muscle hyperplasia of arterioles, the presence of perivascular lymphocytic infiltrates in the duct wall.

Keywords: Microstructure, bile excretion pathways, white rat, Nalbuphine.
\end{abstract}

\section{Introduction}

The morphological state of the bile ducts remains one of the most pressing problems of modern medical science $[5,6,13,17]$. Damage to the bile ducts often poses a serious threat to the patient's life $[4,24,26]$. In $12-30 \%$ of patients operated on for cholecystitis or bile duct damage, scars and, accordingly, scar strictures of the common bile duct are formed in the postoperative period [2]. Therefore, especially many works are devoted to the tactics of surgical treatment of bile duct pathology [3, 7, 9, 34].

Studying histological changes in the common bile duct after long placement of a metal stent in animals, inflammation, fibrosis and trauma of the epithelium, an increase in the number of lymphoid follicles, a high degree of neutrophilic infiltration, the presence of ulcers of the mucous membrane were observed [22]. Recent advances in tissue engineering make it possible to create an intrahepatic bile duct tree. It has been proposed to induce the formation of bile ducts using encapsulated immortalized epithelial cells of the mucous membrane of the bile ducts of mice using decelularized hydrogels of the extracellular matrix of the liver [23]. Some works are devoted to the therapeutic treatment of bile duct pathology $[11,14$, 35]. Successful treatment of biliary outflow difficulties was achieved by combination therapy, which included the 
introduction of drugs into the portal vein and common bile duct [21].

Opioids, in particular morphine, are often used to obtain an analgesic effect in patients with acute cholangitis [12]. However, in the professional literature there are only a few works devoted to the study of the mechanism of action of opioids [8]. Information on the effectiveness of opioids in the treatment of pathological conditions of the bile ducts is often contradictory. The rapidly progressive destruction of the intrahepatic bile ducts associated with the use of narcotic agents has been described [20]. Among the nonobstructive etiologies of bile duct dilation, opioid consumption predominates [10].

The above determined the purpose of our study - to establish the features of the morphological state of the common bile duct under conditions of six weeks of opioid exposure in the experiment.

\section{Materials and methods}

The studies were performed on 24 adult white male rats weighing $180-200 \mathrm{~g}$ and aged $3.5-5.0$ months. All experimental animals were divided into 3 series: in the first series ( 5 rats) studied the structural organization of the common bile duct wall of white rats after 2 weeks of Nalbuphine administration, in 2 series of experiments (5 rats) studied changes in the microstructure of the common bile duct after 4 weeks, and in 3 series of experiments ( 5 rats) reorganization of the wall of the common bile duct of experimental animals after 6 weeks of Nalbuphine administration. The control group included 9 white rats treated with $0.9 \%$ sodium chloride solution.

The study material is represented by histological preparations of the common bile duct of white rats. For histological examination, sections were stained with hematoxylin and eosin. The preparations were studied and photographed under microscope magnifications: $x 200$, $x 400, x 1000$. The "Aver Media" computer system was used to photograph the micropreparations. The computer program ImageJ was used to measure the diameter of the lumen and the wall thickness of the common bile duct. For statistical processing of the received digital data the software "Excel" and "STATISTICA" 6.0 were used.

Administration of Nalbuphine was performed intramuscularly according to the following scheme: I week - $8 \mathrm{mg} / \mathrm{kg}$, II week - $15 \mathrm{mg} / \mathrm{kg}$, III week - $20 \mathrm{mg} / \mathrm{kg}$, IV week - $25 \mathrm{mg} / \mathrm{kg}$, V week - $30 \mathrm{mg} / \mathrm{kg}$, week VI - $35 \mathrm{mg} / \mathrm{kg}$.

All animals were kept in the vivarium of Danylo Halytsky Lviv National Medical University. The experiments were carried out in accordance with the provisions of the European Convention for the Protection of Vertebrate Animals Used for Experimental and Other Scientific Purposes (Strasbourg, 1986), Council Directive 86/609/ EEC (1986), Law of Ukraine № 3447 - IV "On the protection of animals from cruelty", general ethical principles of animal experiments, approved by the First National Congress of Ukraine on Bioethics (2001).

\section{Results}

After 2 weeks of administration of Nalbuphine to white rats, the structural organization of the common bile duct wall of experimental animals, as well as control animals, is mainly preserved and represented by mucous, muscular and adventitial membranes (Fig. 1). The mucous membrane of the wall of the common bile duct is lined with prismatic epithelium, which was adjacent to its own plate, formed by a layer of connective tissue. Epithelial cells cholangiocytes - had a typical structure, distinct apical, basal and lateral surfaces (the latter in contact with each other), a large oval nucleus with clear contours. In its own plate clearly visible single, but rather large glands with preserved structure. On some histological preparations of this term of experiment we found increase in number of glands in a wall of a common bilious channel, proliferation of their epithelium (Fig. 2). The muscular membrane consisted of smooth myocytes arranged in bundles with a preserved helical arrangement. The adventitial membrane is rich in

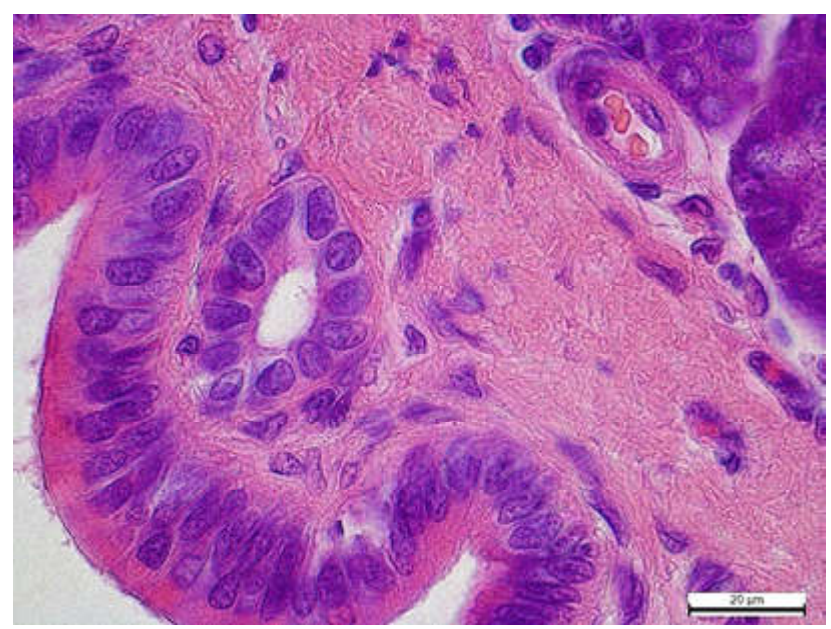

Fig. 1. A fragment of the common bile duct of a white rat after 2 weeks of the experiment. Hematoxylin-eosin. Photomicrograph. $\mathrm{x} 1000$.

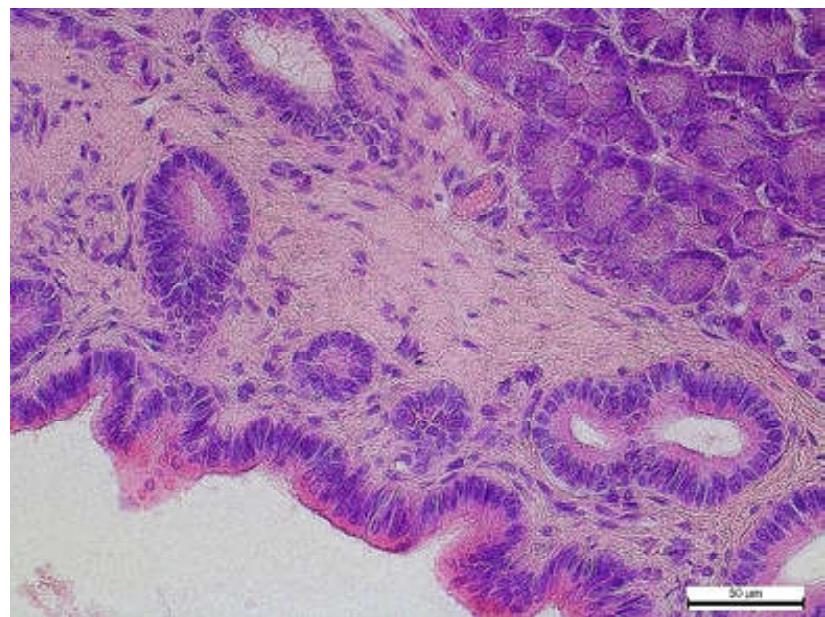

Fig. 2. A fragment of the common bile duct of a white rat after 2 weeks of the experiment. Hematoxylin-eosin. Photomicrograph. $\mathrm{x} 400$. 


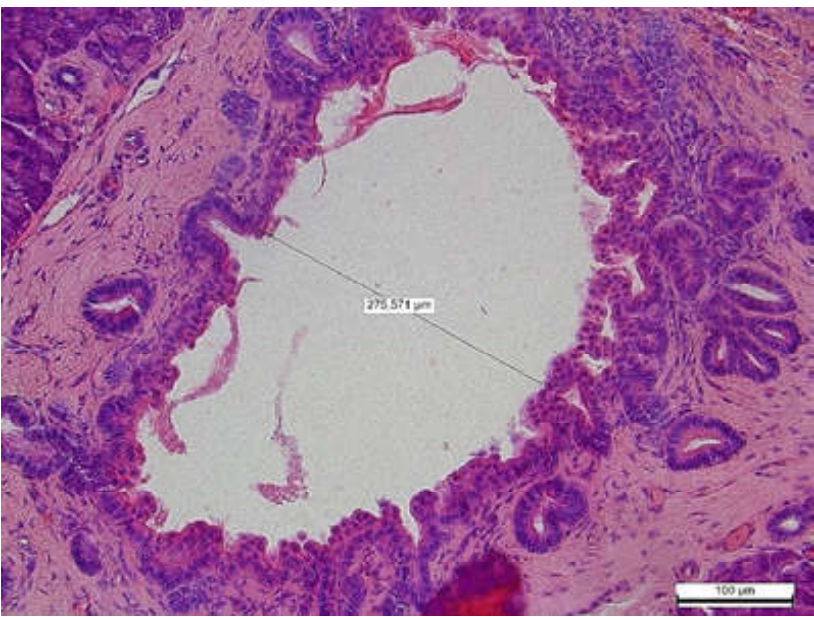

Fig. 3. A fragment of the common bile duct of a white rat after 4 weeks of the experiment. Hematoxylin-eosin. Photomicrograph. x200.

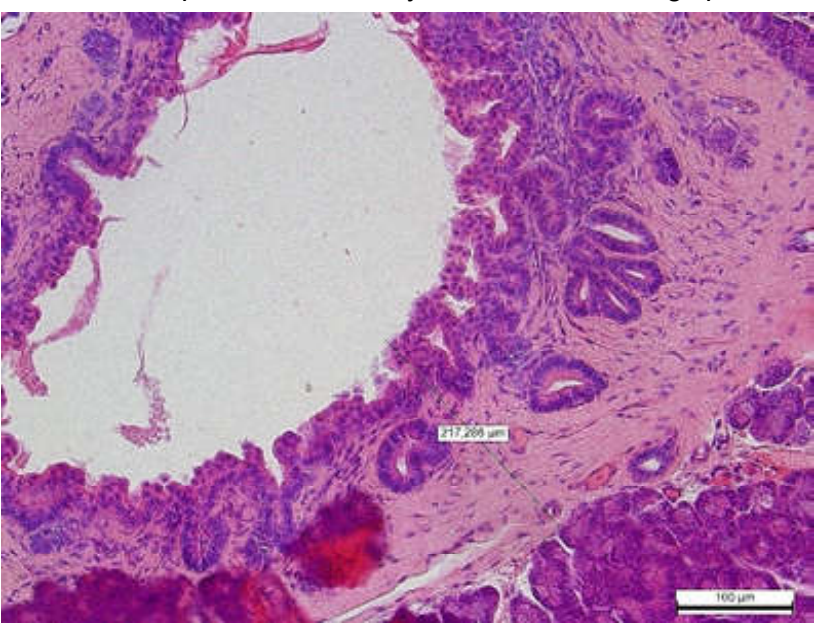

Fig. 4. A fragment of the common bile duct of a white rat after 4 weeks of the experiment. Hematoxylin-eosin. Photomicrograph. x200.

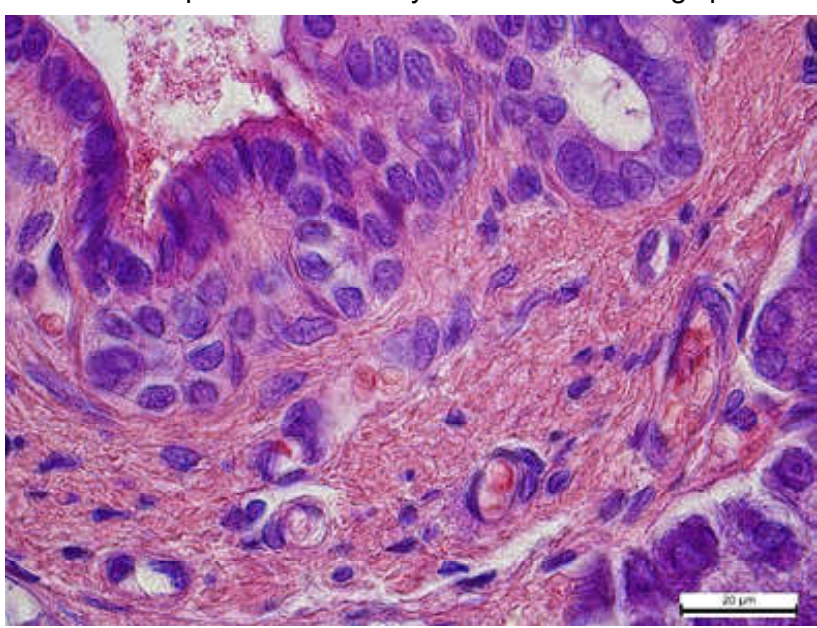

Fig. 5. A fragment of the common bile duct of a white rat after 6 weeks of the experiment. Hematoxylin-eosin. Photomicrograph. x1000.

vessels, which at this time of the experiment are full-blooded (especially arterioles and capillaries, as shown in Fig. 1) and dilated.
Morphometric analysis of histological specimens revealed that the lumen of the common bile duct of white rats in cross section has an oval shape, so we considered it appropriate to measure the longitudinal diameter of the lumen of the common bile duct, which was at this time of the experiment $272.77 \pm 15.09 \mu \mathrm{m}$ (control $-126.97 \pm 3.19 \mu \mathrm{m}$, $\mathrm{p}<0.05)$, and the transverse diameter $-97.36 \pm 10.86 \mu \mathrm{m}$ (control - 72.79 $\pm 13.52 \mu \mathrm{m}, \mathrm{p}>0.05$ ), wall thickness of common bile duct was 137.85 $\pm 14.41 \mu \mathrm{m}$ (control $144.77 \pm 3.91 \mu \mathrm{m}, \mathrm{p}>0.05$ ).

A significant increase in the longitudinal diameter of the lumen of the common bile duct indicates a change in the shape of its lumen due to two weeks of Nalbuphine introduction. In addition, although the change in the wall thickness of the common bile duct after 2 weeks of the experiment is not significant, but the maximum value of this indicator in experimental animals $(152.52 \mu \mathrm{m})$ is much larger than its maximum value in control animals $(148.69 \mu \mathrm{m})$, which indicates about increasing the wall thickness of the common bile duct during this period of the experiment.

After 4 weeks of experimental exposure to Nalbuphine, the shape of the lumen of the common bile duct is incorrect, cholangiocytes are often without clear contours, their nuclei are large, deformed, swollen, observed epithelial protrusions, and in some places - exfoliation of epitheliocytes into the lumen of the common bile duct (Fig. 3).

The own plate is swollen, fluffy, in some places stratified, glands are destructured, shifted in the direction of an epithelial layer, in their gleams - stagnation of secretion. The bundles of smooth muscle myocytes are stratified, partially losing their helical organization. The connective tissue of the adventitial membrane is in a state of edema, the arterioles are dilated, their wall is thickened, parietal thrombi are formed in the lumens, capillaries are hyperemic, often the capillary wall is damaged, diapedetic hemorrhages are found, venules are dilated, the walls of the venules are thinned (Fig. 4). Morphometric analysis showed a pronounced dilatation of the common bile duct, the longitudinal diameter of the lumen of the duct increased to $462.98 \pm 24.15 \mu \mathrm{m}(\mathrm{p}<0.05)$, the transverse diameter to $275.57 \pm 18.34 \mu \mathrm{m}(\mathrm{p}<0.05)$, as can be seen from Figure 2 . The wall thickness of the common bile duct significantly $(p<0.05)$ increased and amounted to $217.29 \pm 18.09 \mu \mathrm{m}$, as shown in Figure 4.

After 6 weeks of the experiment, the wall of the common bile duct is destructed, it was often difficult to differentiate the boundaries of its membranes, the cholangiocyte layer is disorganized, formed numerous folds, in some places thinning of the epithelial layer due to detachment of cholangiocytes, cholangiocytes acquired a flattened shape, noted the polymorphism of their nuclei, the nuclei lost their location in the center of the cell, shifted to the apical surface of the cell, intercellular contacts are broken, expanded (Fig. 5).The own plate of a wall of a common bilious channel is stratified, gleams of glands are uneven, have lost the 
correct form, mainly expanded, filled with contents. The bundles of smooth myocytes are separated by coarse layers of connective tissue, there is a vacuolar dystrophy of the muscular membrane, the adventitial membrane is in a state of edema, sometimes not differentiated.

When performing morphometric analysis, it was often impossible to determine the transverse diameter of the lumen of the common bile duct, because its walls collapsed (glued), the lumen of the duct was deformed, the longitudinal diameter of the lumen ranged from $294.88 \mu \mathrm{m}$ to $386.46 \mu \mathrm{m}$ $(p<0.05)$, the wall thickness of the common bile duct was $176.44 \pm 26.34 \mu \mathrm{m}$, which is significantly more than the control animals, but significantly less than the experimental animals in the previous period of the experiment, which confirms the development of dystrophic-degenerative processes in the common bile duct wall after 6 weeks exposure to Nalbuphine. During this period of the experiment, significant changes in the vessels of the hemomicrocirculatory tract of the common bile duct, including dilation of venules, significant smooth muscle hyperplasia of the portal arterioles were also detected. It should be noted that due to plasma infiltration, sclerosis and hyalinosis, the wall of the arterioles was thickened, and perivascular edema and lymphocytic infiltrates were observed.

\section{Discussion}

The results of research presented in the professional literature mainly indicate the negative impact of long-term use of opioids on the structural organization of organs and tissues [29]. At the heart of the development of pathological processes due to the action of narcotic drugs is often angiopathy [25, 27], which is confirmed in our studies.

A characteristic feature of the effect of Nalbuphine on the wall structure of the common bile duct is its dilatation. According to the literature, opioids can cause an increase in the basic pressure and frequency of phase contractions of the sphincter of Oddi, which leads to dilation of the common bile duct [10]. The author describes an association between elevated bile duct diameter and opioid dependence even in patients without clinical symptoms, normal bilirubin and alkaline phosphatase, and no obstructive factors. On histological specimens we found nonspecific morphological changes in the components of the common bile duct, as degeneration of the epithelial layer of its mucous membrane, lymphocytic infiltration, microvascular hyperemia is characteristic of cholangitis of

\section{References}

[1] Abshagen, K., Kцnig, M., Hoppe, A., Mьller, I., Ebert, M., Weng, H. ... Dooley, S. (2015). Pathobiochemical signatures of cholestatic liver disease in bile duct ligated mice. BMC Syst. Biology, 9, 83. doi: 10.1186/s12918-015-0229-0

[2] Burden, N., Kendrick, J., Knight, L., McGregor, V., Murphy, H., Punler, M., \& van Wijk, H. (2017). Maximizing the success of bile duct cannulation studies in rats: recommendations for best practice. Lab. Anim., 51(5), 457-464. doi: 10.1177/ 0023677217698001 various etiologies. Epithelial cells of the bile duct mucosa can serve as antigens to activate the cells of the natural killer T [31]. The bile ducts dilate, cholestasis develops, and lymphocytic infiltrates appear around the bile ducts. Inflammation of the bile duct (cholangitis) is based mainly on bile stasis, which leads to its thickening, sludge and subsequent infection, or, conversely, acute inflammation of the bile ducts (cholangitis) causes impaired bile flow [18, 32].

An important finding of our study is the degenerative changes in the later stages of the experiment of the muscular membrane of the wall of the common bile duct. Experiments have shown that damage to the muscular layer of the bile duct leads to the development of liver cirrhosis [16, 19, 28, 33] and even hepatocellular carcinoma [1, 30]. Significant collagen deposition, portal fibrosis, periductal edema, lymphocytic inflammation, dilatation of all bile ducts, blind end of small bile ducts, cholestasis (bile corks), increased systemic oxidative stress, and fibrosis were observed in rats after ligature was applied to the common bile duct, which eventually leads to liver cirrhosis [15, 32].

In the future, subject to long-term use of opioids, the results of this study can be used in practical medicine for the diagnosis and treatment of pathological conditions of the intrahepatic bile ducts.

\section{Conclusions}

Plethora of microvessels of the wall and a significant increase in the longitudinal diameter of the lumen of the common bile duct was observed after 2 weeks of administration of Nalbuphine to white rats.

After 4 weeks of the experiment, the common bile duct was dilated, the transverse and longitudinal diameters of its lumen almost doubled, pathological changes in its wall had all the signs of inflammation.

In the later stages of the experiment (introduction of Nalbuphine for 6 weeks) pathological changes increased and manifested by destructuring of the common bile duct wall, disorganization of cholangiocytes, thinning of the cell layer due to detachment of cholangiocytes, polymorphism of their nuclei, destruction of intercellular contacts, stratification of own plate, vacuolar dystrophy of a muscular cover, "varicose" expansion of venules, expressive smooth muscular hyperplasia of arterioles, existence of perivascular lymphocytic infiltrates in a channel wall.

[3] Buturovic S. (2014). latrogenic Injury to the Common Bile. Duct. Med. Arch., 68(4), 291-293. doi: 10.5455/medarh.2014.68

[4] Carmody, I. C., Romano, J., Bohorquez, H., Bugeaud, E., Bruce, D. S., Cohen, A. J. ... Loss, G. E. (2017). Novel Biliary Reconstruction Techniques During Liver Transplantation. Ochsner J., 17(1), 42-45. PMID: 28331447

[5] Cheng, Y., Xiong, X. Z., Zhou, R. X., Deng, Y. L., Jin, Y. W., Lu, J. ... Cheng, N. S. (2016). Repair of a common bile duct defect with a decellularized ureteral graft. World J. Gastroenterol., 
22(48), 10575-10583. doi: 10.3748/wjg.v22.i48.10575

[6] Cho, H. J., Jwa, H. J., Kim, K. S., Gang, D. Y., \& Kim, J. Y. (2013) Urosodeoxycholic Acid Therapy in a Child with TrimethoprimSulfamethoxazole-induced Vanishing Bile Duct Syndrome. Pediatr. Gastroenterol. Hepatol. Nutr., 16(4), 273-278. doi: 10.5223/pghn.2013.16.4.273

[7] Chun, K. (2014). Recent classifications of the common bile duct injury. Korean J. Hepatobiliary Pancreat. Surg., 18(3), 69-72. doi: 10.14701/kjhbps.2014.18.3.69

[8] Dai, J., Wu, X. F., Yang, C., Li, H. J., Chen, Y. L., Liu, G.Z. ... Li, N. (2015). Study of Relationship Between the Blood Supply of the Extrahepatic Bile Duct and Duct Supply Branches from Gastroduodenal Artery on Imaging and Anatomy. Chin. Med. J. (Engl), 128(3), 322-326. doi: 10.4103/0366-6999.150097

[9] Darkahi, B., Liljeholm, H., \& Sandblom, G. (2016). Laparoscopic Common Bile Duct Exploration: 9-Years Experience from a Single Center. Front. Surg., 3, 23. doi: 10.3389/ fsurg.2016.00023

[10] DeAngelis, C., Marietti, M., Bruno, M., Pellicano, R., \& Rizzetto, M. (2015). Endoscopic ultrasound in common bile duct dilatation with normal liver enzymes. World J. Gastrointest. Endosc., 7(8), 799-805. doi: 10.4253/wjge.v7.i8.799

[11] Fahmy, S. R. (2015). Anti-fibrotic effect of Holothuria arenicola extract against bile duct ligation in rats. BMC ComplementAltern. Med., 15, 14. doi: 10.1186/s12906-015-0533-7

[12] Farnia, M. R., Babaei, R., Shirani, F., Momeni, M., Hajimaghsoudi, M., Vahidi, E., \& Saeedi, M. (2016). Analgesic effect of paracetamol combined with low-dose morphine versus morphine alone on patients with biliary colic:a double blind, randomized controlled trial. World J. Emerg. Med., 7(1), 2529. doi: 10.5847/wjem.j.1920-8642.2016.01.004

[13] Fazeli Dehkordy, S., Fowler K. J., Wolfson, T., Igarashi, S., Lamas Costantino, C. P., Hooker, J. C. ... Sirlin, C. B. (2018). Technical report: gadoxetate-disodium-enhanced 2D R2* mapping: a novel approach for assessing bile ducts in living donors. Abdom. Radiol. (NY), 43(7), 1656-1660. doi: 10.1007/ s00261-017-1365-3

[14] Fenner, E. K., Boguniewicz, J., Tucker, R. M., Sokol, R. J., \& Mack, C. L. (2014). High Dose IgG Therapy Mitigates Bile Duct Targeted Inflammation and Obstruction in a Mouse Model of Biliary. Atresia Pediatr. Res., 76(1), 72-80. doi: 10.1038/ pr.2014.46

[15] Garrido, M., Escobar, C., Zamora, C., Rejas, C., Varas, J., P?rraga, M. ... Montedonico S. (2017). Bile duct ligature in young rats: A revisited animal model for biliary atresia. Eur. J. Histochem., 61:2803, 249-254. doi: 10.4081/ejh.2017.2803

[16] Giusto, M., Barberi, L., Di Sario, F., Rizzuto, E., Nicoletti, C., Ascenzi, F., Renzi, A. ... Merli, M. (2017). Skeletal muscle myopenia in mice model of bile duct ligation and carbon tetrachloride?induced liver cirrhosis. Physiol. Rep., 5(7), 113. doi: $10.14814 /$ phy2.13153

[17] Gudnason, H. O., \& Bjцrnsson, E. S. (2017). Secondary sclerosing cholangitis in critically ill patients:current perspectives. Clin. Exp. Gastroenterol., 10, 105-111. doi: 10.2147/CEG.S115518

[18] Hatano, R., Akiyama, K., Tamura, A., Hosogi, S., Marunaka, Y., Caplan, M. J. ... Asano, S. (2015). Knockdown of Ezrin Causes Intrahepatic Cholestasis by the Dysregulation of Bile Fluidity in the Bile Duct Epithelium in Mice. Hepatology, 61(5), 1660-1671. doi: 10.1002/hep.27565

[19] Jiang, J., Wei, J., Wu, J., Gao, W., Li, Q., Jiang, K., \& Miao, Y. (2016). Partial Portal Vein Arterialization Attenuates Acute Bile Duct Injury Induced by Hepatic Dearterialization in a Rat Model.
Biomed. Res. Int., 2016, 1-14. doi: 10.1155/2016/7427246

[20] Kim, H. Y., Yang, H. K., Kim, S. H., \& Park, J. H. (2014). Ibuprofen Associated Acute Vanishing Bile Duct Syndrome and Toxic Epidermal Necrolysis in an Infant. Yonsei Med. J., 55(3), 834837. doi: 10.3349/ymj.2014.55.3.834

[21] Kubo, N., Harimoto, N., Shibuya, K., Ishii, N., Tsukagoshi, M., Igarashi, T. ... Shirabe, K. (2018). Successful treatment of isolated bile leakage after hepatectomy combination therapy with percutaneous transhepatic portal embolization and bile duct ablation with ethanol: a case report. Surg. Case Rep., 4, 1-5. doi: 10.1186/s40792-018-0463-y

[22] Lee, S. S., Song, T. J., Joo, M., Park, D. H., Seo, D. W., Lee, S. K., \& Kim, M. H. (2014). Histological Changes in the Bile Duct after Long-Term Placement of a Fully Covered Self- Expandable Metal Stent within a Common Bile Duct: A Canine Study. Clinical Endoscopy, 47(1), 84-93. doi: 10.5946/ce.2014.47.1.84

[23] Lewis, P. L., Su, J., Yan, M., Meng, F., Glaser, S. S., Alpini, G. D. ... Shah, R. N. (2018). Complex bile duct network formation within liver decellularized extracellular matrix hydrogels. Sci. Rep., 8, 1-14. doi: 10.1038/s41598-018-30433-6

[24] Li, S. Q., Hua, Y. P., Shen, S. L., Hu, W. J., Peng, B. G., \& Liang, L. J. (2015). Segmental Bile Duct-Targeted Liver Resection for Right-Sided Intrahepatic Stones. Medicine (Baltimore), 94(28), 1-7. doi: 10.1097/MD.0000000000001158

[25] Mateshuk-Vatseba, L., Kost, A., \& Pidvalna, U. (2018). Effect of Narcotic Analgesics on the Ultrastructure of the Eyeball (Experimental Study). Journal of Morphological Sciences. Georg Thieme Verlag KG, 35(04), 251-254. Available from: http://dx.doi.org/10.1055/s-0038-1676543

[26] Miethke, A. G., Zhang, W., Simmons, J., Taylor, A., Shi, T., Shanmukhappa, S. K. ... Setchell, K. D. R. (2016). Pharmacological inhibition of ASBT changes bile composition and blocks progression of sclerosing cholangitis in mdr2 knockout mice. Hepatology, 63(2):512-523. doi: 10.1002/ hep. 27973

[27] Pokotylo, V. U. (2017). Peculiarities of myocardial ultrastructure of rats at the late terms of opioid intoxication. Deutscher Wissenschaftsherold, 6, 14-20.

[28] Sheen, J. M., Chen, Y. C., Hsu, M. H., Tain, Y. L., Huang, Y. H., Tiao, M. M. ... Huang, Li-T. (2016). Melatonin Alleviates Liver Apoptosis in Bile Duct Ligation Young Rats. Int. J. Mol. Sci., 17(8), 1365. doi: 10.3390/ijms17081365

[29] Soleimanpour, H., Safari, S., Shahsavari, N. K., Sanaie, S., \& Alavian, S. M. (2016). Opioid Drugs in Patients With Liver Disease: A Systematic Review. Hepat. Mon., 16(4), e32636. doi: 10.5812/hepatmon.32636

[30] Tag, C. G., Sauer-Lehnen, S., Weiskirchen, S., BorkhamKamphorst, E., Tolba, R. H., Tacke, F., Weiskirchen, R. ... (2015). Bile Duct Ligation in Mice:Induction of Inflammatory Liver Injury and Fibrosis by Obstructive Cholestasis. J. Vis. Exp., 96, 52438. doi: $10.3791 / 52438$

[31] Tomizawa, M., Shinozaki, F., Hasegawa, R., Shirai, Y., Motoyoshi, Y., Sugiyama, T. ... Ishige, N. (2017). Comparison of acute cholangitis with or without common bile duct dilatation. Exp. Ther. Med., 13(6), 3497-3502. doi: 10.3892/etm.2017.4401

[32] Van Thuy, T. T., Thuy, L. T., Yoshizato, K., \& Kawada, N. (2017). Possible Involvement of Nitric Oxide in Enhanced Liver Injury and Fibrogenesis during Cholestasis in Cytoglobindeficient Mice. Scientific Reports, 7(1), 41888, 1-14. doi: 10.1038/srep41888

[33] Xuan, R., Zhao, X., Hu, D., Jian, J., Wang, T., \& Hu, C. (2015). Three-dimensional visualization of the microvasculature of bile duct ligation-induced liver fibrosis in rats by $\mathrm{x}$-ray phase- 
contrast imaging computed tomography. Scientific Repots, 5(1), 11500. doi: $10.1038 /$ srep 11500

[34] Yang, Y. L, Zhang, C., Zhang, H. W., Wu, P., Ma, Y. F., Lin, M. J. ... Zhao, M. (2015). Common bile duct injury by fibrin glue: Report of a rare complication. World J. Gastroenterol., 21(9), 2854-2857. doi: 10.3748/wjg.v21.i9.2854
[35] Zhen, Y. Z., Li, N. R., He, H. W., Zhao, S. S., Zhang, G. L., Hao, X. F., \& Shao, R. G. (2015). Protective effect of bicyclol against bile duct ligation-induced hepatic fibrosis in rats. World $\mathrm{J}$. Gastroenterol., 21(23), 7155-7164. doi: 10.3748/wjg.v21.i23.

\section{МОРФОЛОГІЧНІ ОСОБЛИВОСТІ СТІНКИ СПІЛЬНОЇ ЖОВЧНОЇ ПРОТОКИ ЗА УМОВ ЕКСПЕРИМЕНТАЛЬНОГО ВПЛИВУ опіоїду \\ Матешук-Вацеба Л.Р., Гірняк І.І., Підвальна У.є.}

Морфологічний стан шляхів виведення жовчі залишається однією з найважливіших проблем сучасної медичної науки. 3 метою отримання анельгезуючого ефректу у пацієнтів із гострим холангітом часто застосовують опіоїди. Проте відомості щодо ефективності застосування опіоїдів для лікування патологічних станів жовчних проток суперечливі. Актуальним $\epsilon$ подальще дослідження дії опіоїдів на структурну організацію спільної жовчної протоки. 3 метою встановлення морфологічного стану спільної жовчної протоки за умов тривалого впливу опіоїду проведено дослідження на 24 статевозрілих білих щурахсамцях, віком 3,5-5,0 місяців і масою тіла 180-200 г, котрим впродовж 6 тижнів внутрішньом'язово вводили налбуфрін. Матеріал дослідження представлений гістологічними препаратами спільної жовчної протоки білих щурів. Для фотодокументування отриманих нами мікропрепаратів була використана комп'ютерна система "Aver Media". Для виміру діаметра просвіту та товщини стінки спільної жовчної протоки застосовували комп'ютерну програму IтаgeJ. Pезультати дослідження свідчать, що через 2 тижні введення налбуфріну білим щурам виникало повнокров'я мікросудин стінки та достовірне збільшення поздовжнього діаметра просвіту спільної жовчної протоки. Через 4 тижні експерименту спільна жовчна протока дилатована, поперечний та поздовжній діаметри ії просвіту зростали майже вдвічі, патологічні зміни ії стінки мали всі ознаки запалення. На пізніх термінах експерименту (введення налбуфріну впродовж 6 тижнів) патологічні зміни наростали і проявлялися деструктуризацією стінки спільної жовчної протоки, дезорганізацією холангіоцитів, стоншенням клітинного пласту внаслідок відшарування холангіоцитів, поліморфоімом їхніх ядер, руйнуванням міжклітинних контактів, розшаруванням власної пластинки, вакуольною дистрофрією м'язової оболонки, "варикозним" розширенням венул, виразною гладком'язовою гіперплазією артеріол, наявністю периваскулярних лімфоцитарних інфрільтратів у стінці протоки. Ключові слова: мікроструктура, шляхи виведення жовчі, білий щур, налбуфін.

\section{МОРФОЛОГИЧЕСКИЕ ОСОБЕННОСТИ СТЕНКИ ОБЩЕГО ЖЕЛЧНОГО ПРОТОКА В УСЛОВИЯХ ЭКСПЕРИМЕНТАЛЬНОГО ВлИЯНИЯ ОПИОИДА \\ Матешук-Вацеба Л.Р., Гирняк И.И., Пидвальна У.Е.}

Морфологическое состояние путей вывода желчи остается одной из важнейших проблем современной медицинской науки. С иелью получения анельгезирующего эффректа у пациентов с острым холангитом часто применяют опиоиды. Однако сведения об эфорективности применения опиоидов для лечения патологических состояний желчных протоков противоречивы. Актуальным является дальнейшее исследование действия опиоидов на структурную организацию общего желчного протока. С целью установления морфологического состояния общего желчного протока в условиях длительного воздействия опиоида проведено исследование на 24 половозрелых белых крысах-самцах в возрасте 3,5-5,0 месяцев и массой тела 180-200 г, которым в течение 6 недель внутримышечно вводили налбуфин. Материал исследования представлен гистологическими препаратами общего желчного протока белых крыс. Для фотодокументирования полученных нами микропрепаратов была использована компьютерная система "Aver Media". Для измерения диаметра просвета и толщины стенки общего желчного протока применяли компьютерную программу ImageJ. Результаты исследования свидетельствуют, что через 2 недели введения налбуфрина белым крысам возникало полнокровие микрососудов стенки и достоверное увеличение продольного диаметра просвета общего желчного протока. Через 4 недели эксперимента общий желчный проток дилятирован, поперечный и продольный диаметры его просвета увеличились почти вдвое, патологические изменения его стенки имели все признаки воспаления. На поздних сроках эксперимента (введение налбуфрина в течение 6 недель) патологические изменения нарастали и проявлялись деструктуризацией стенки общего желчного протока, дезорганизацией холангиоцитов, истончением клеточного пласта в результате отслоения холангиоцитов, полиморфизмом их ядер, разрушением межклеточных контактов, расслоением собственной пластинки, вакуольной дистрофией мышечной оболочки, "варикозным" расширением венул, выраженной гладкомышечной гиперплазией артериол, наличием периваскулярных лимфоцитарных инфрильтратов в стенке протока.

Ключевые слова: микроструктура, пути выведения желчи, белая крыса, налбуфин. 